\title{
Pemberdayaan Masyarakat Melalui Tanaman Obat Keluarga (TOGA)
}

\author{
Muhammad Eko Atmojo', Awang Darumurti² \\ 1,2Program Studi Ilmu Pemerintahan Universitas Muhammadiyah Yogyakarta \\ email: 1atmojoeko91@gmail.com, 2awangdarumurti@yahoo.com
}

\begin{abstract}
Abstrak
Pelaksanaan pengabdian ini dilakukan di Desa Singoyudan dengan skema KKNPPM. Jika dilihat berdasarkan letak geografis Desa Singoyudan adalah desa yang berada di wilayah pesisir sehingga mayoritas masyarakatnya bertani. Selain itu desa ini memepunyai potensi untuk dikembangkan, salah satunya jumlah tanaman yang dapat digunakan sebagai obat keluarga. Metode yang dilakukan pada pelaksnaaan pengabdian meliputi sosialisasi, pelatihan pembuatan obat melalui tanaman, dan pembuatan kebun tanaman obat keluarga. Hasilnya adalah tersedianya lahan atau perkebunan tanaman keluarga yang dapat dikelola dan dimanfaatkan oleh masyarkaat, terutama oleh ibu-ibu PKK. Selain itu juga masyarakat Desa Singoyudan memperoleh pemahaman dan wawasan tentang manfaat tanaman di sekitar untuk dijadikan sebagai obat pendamping keluarga.
\end{abstract}

Kata Kunci: Tanaman Obat Keluarga, Sosialisasi, Pelatihan

\begin{abstract}
This service is carried out in Singoyudan Village with the KKN-PPM scheme. If viewed from the geographical location, Singoyudan Village is a village located in a coastal area so that the majority of the people are farming. Also, this village has the potential to be developed, one of which is the number of plants that can be used as family medicine. The methods used in the community service implementation include socialization, training in making medicine through plants, and making a garden for family medicinal plants. The result is the availability of land or family plantations that can be managed and utilized by the community, especially by PKK women. Besides, the people of Singoyudan Village gain understanding and insight into the benefits of plants around them to be used as family companion medicines.
\end{abstract}

Keywords: Family Medicinal Plants, Socialization, Training

\section{Pendahuluan}

Desa Singoyudan merupakan salah satu desa yang berada di daerah pesisir pantai selatan dan perbatasan dengan Kabupaten Purworejo. Jika dilihat berdasarkan letak geografis daerah ini mempunyai potensi dibidang pertanian yang sangat luas, serta mayoritas mata pencaharian masyarakatnya adalah bertani. Hal ini juga didukung dengan adanya kesuburan tanah di daerah Desa Singoyudan, dengan adanya kesuburan tanah tersebut maka sangat cocok untuk dijadikan sebagai wahana bertani. 
Dengan adanya kesuburan tanah yang ada di Desa Singoyudan tersebut maka ada beberapa keuntungan yang didapat, salah satunya adalah dukungan dari Dinas Pertanian Kabupaten Kebumen. Dukungan tersebut mengenai tanaman keluarga, hal ini sangat diperlukan di desa Singoyudan, mengingat letak geografis yang sangat jauh dari perkotaan dan mempunyai tanah yang subur maka tanaman keluarga cocok untuk pendamping masyarakat desa tersebut. Tanaman pendamping ini bisa dalam bentuk tanaman obat keluarga maupun tanaman yang lain.

Berdasarkan hasil observasi yang telah kami lakukan ada beberapa hal yang menjadi permasalahan di Desa Singoyudan, diantaranya adalah minimnya pemanfaatan tanaman sekitar untuk dijadikan sebagai obat-obatan, seperti kencur, jahe dan lainlain. Masih banyaknya pekarangan yang kosong di Desa Singoyudan, sehingga bisa dimanfaatkan sebagai lahan penanaman obat keluarga atau apotek hidup. Selain itu pemerintah desa juga fokus kepada masalah stunting, mengingat Kecamatan Mirit merupakan salah satu kecamatan yang rawan tentang permasalahan stunting. Berdasarkan data Dinas Kesehatan bahwa Kabupaten Kebumen sedikitnya terdapat 124 balita menderita stunting, dan khususnya Kecamatan Mirit terdapat 22 balita menderita stunting (https:/ / bag-humas.kebumenkab.go.id).

Dengan tingginya angka stunting di Kecamatan Mirit maka Pemerintah Desa Singoyudan menerapkan peduli stunting, hal ini merupakan salah satu program pemerintah desa. Dengan adanya peduli stunting ini akan sangat baik bagi masyarakat Desa Singoyudan, terutama untuk tetap hidup sehat. Salah satu cara untuk mengatasi masalah kesehatan adalah dengan melakukan atau mengkampanyekan pola hidup sehat, maupun olahraga kepada masyarakatnya. Selain itu berdasarkan pernyataan (Qamariah, Handayani, \& Novaryatiin, 2019) bahwa pemerintah desa bisa melakukan kampanye penyediaan tanaman yang berfungsi sebagai obat herbal di pekarang masyarakat, sehingga bisa membantu dalam mengatasi permasalahan kesehatan di desa tersebut.

Penyediaan tanaman yang berfungsi sebagai obat-obatan ini juga bisa mengatasi permasalahan minimnya infrastruktur penunjang seperti apotik, rumah sakit terdekat dan lain-lain. Selain itu hal ini juga bisa sebagai salah satu alternative dalam mengatasi lemahnya daya beli masayarakat dan melambungnya harga obat-obatan modern yang memaksa masyarakat dan pemerintah mencari upaya mengatasi keadaan ini dengan cara kembali ke alam (Nurjanah, Nurazizah, Septiana, \& Shalikhah, 2019). Cara ini merupakan salah satu cara yang paling efisien dalam mengatasi permasalahan kesehatan di lingkungan masyarakat.

Penggunaan tanaman sebagai alternative obat juga didasari dengan tingginya obat herbal yang mulai di promosikan dikalangan masayarakat. Banyak sekali produkproduk herbal yang sekarang sudah mulai berkembang dan beredar di kalangan masyarakat. Sesuai dengan pernyataan dari (Susanto, 2017) bahwa dengan peningkatan penggunaan obat-obatan berbahan herbal di dunia yang semakin meningkat, ini ternyata berbanding terbalik dengan kesadaran masyarakat untuk mengusahakan sendiri obat-obatan yang berbahan dasar herbal. Obat-obatan yang berasal dari tanaman ini memang sudha banyak sekali dikonsumsi oleh masyarakat 
Indonesia, hal ini dikarenakan harganya relative lebih murah serta sangat mudah didapatkan dilingkungan sekitar. Selain itu berdasarkan pernyataan Katno dalam (Karo-Karo, 2010) bahwa masyarakat lebih menyukai obat-obatan yang berasal dari tanaman dikarenakan efek samping yang rendah, efek yang saling mendukung dengan obat tradisional lain, lebih sesuai untuk berbagai penyakit metabolik dan degenerative.

Salah satu tujuan kegiatan ini adalah untuk meningkatkan pengetahuan dan pemahaman serta pemanfaatan masyarakat Desa Singoyudan dalam pengelolaan tanaman disekitar. Sehingga tanaman yang banyak tumbuh tersebut mempunyai manfaat bagi masyarakat desa sebagai bahan atau obat keluarga. Selain itu manfaat adanya kegiatan ini adalah meningkatkan daya saing masyarakat dalam hal pemberdayaan, sehingga masyarakat Desa Singoyudan bisa lebih mandiri terutama dalam halo bat pendamping keluarga, karena bisa memanfaatkan tanaman disekitar dan apotek hidup yang telah dibuat.

Maka dari itu, penggunaan obat-obat herbal ini sebenarnya sangat mungkin dan sangat bisa dilakukan oleh masyarakat Desa Singoyudan, mengingat di daerah ini banyak sekali tumbuhan yang bisa dijadikan sebagai bahan obat-obatan herbal. Akan tetapi hal ini masih jarang sekali dilakukan oleh masyarakat, mengingat memang masih minimnya pengetahuan masyarakat dalam mengolah tanaman yang ada menjadi obat-obatan herbal atau pendamping obat keluarga. Maka dari itu, dengan adanya tanaman tersebut maka perlu adanya peningkatan pengetahuan kepada masyarakat dalam memanfaatkan tanaman disekitar untuk dijadikan sebagai tanaman obat keluarga.

\section{Metode}

Pelaksanaan kegiatan KKN-PPM yang dilakukan di Desa Singoyudan harapannya akan membawa dampak positif bagi masyarakat. Maka dari itu demi tercapainya hasil yang maksimal dalam pelaksanaan pengabdian masyarakat ini ada beberapa tahapan atau metode kajian yang digunakan untuk menyelesaikan permasalahan yang ada, diantaranya adalah sebagai berikut:

1. Observasi, merupakan salah satu kegiatan yang paling pokok dalam pelaksanaan pengabdian, terutama pengabdian dengan skema KKN-PPM. Dimana kegiatan ini dilakukan sebelum penetapan tempat, sehingga tim pengabdian melakukan pemetaan permasalahan di Desa Singoyudan, sehingga dengan adanya data pemetaan permasalahn tersebut bisa disimpulkan tema yang akan diambil dalam pelaksanaan pengabdian masyarakat.

2. Sosialisasi dan penyuluhan manfaat tanaman obat keluarga, kegiatan ini dilakukan karena merupakan salah satu komponen yang paling penting dalam pelaksanaan pengabdian masyarakat. Adapun sasaran dari kegaitan sosialisasi adalah masyarakat Desa Singoyudan Kecamatan Mirit Kabupaten Kebumen, khususnya ibu-ibu PKK. Maksud dan tujuan dari kegaitan sosialisasi ini adalah untuk memberikan pemahaman dan pengetahuan bagi masyarakat dalam memanfaatkan tanaman yang ada. Selain itu sosialisasi ini juga memberi 
pengetahuan bagi masyarakat terutama dalam hal kandungan dan mafaat tanaman terhadap jenis penyakit.

3. Pembuatan kebun tanaman obat keluarga, pada pelaksanaan pembuatan kebun tanaman obat keluarga ini diikuti oleh seluruh masyarakat, khususnya ibu-ibu PKK. Mengingat pada pelaksanaan pengabdian ini kebun merupakan salah satu media dalam penanaman tanaman obat keluarga. Pembuatan kebun tanaman obat keluarga juga dipusatkan supaya mudah diawasi dan dirawat, sehingga masyarakat bisa menggunakan tanaman-tanaman yang sudah ditanam tersebut.

\section{Hasil dan Pembahasan}

Pelaksanaan pengabdian dengan skema KKN-PPM merupakan salah satu bentuk tri dharma perguruan tinggi yang dilakukan oleh dosen dan mahasiswa. Dengan adanya kegiatan ini akan banyak sekali manfaatnya bagi masyarakat maupun mahasiswa, terutama dalam hal transfer knowledge maupun sharing mengenai kehidupan sehari-hari dalam bermasyarakat. Selain itu mahasiswa juga bisa melakukan implementasi teori yang didapatkan dari bangku perkuliahan kepada masyarakat.

Pada pelaksanaan kegaitan pengabdian masyarakat ini tema yang diambil adalah pemberdayaan masyarakat melalui tanaman obat keluarga di Desa Singoyudan, Kecamatan Mirit Kabupaten Kebumen. Mengingat hal ini merupakan salah satu komponen terpenting dalam kehidupan sehari-hari terutama bagi masyarakat. Begitu juga dengan masyarakat di Desa Singoyudan, dengan keadaan geografis di daerah pesisir pantai maka sangat tepat sekali jika ada pemberdayaan masyarakat melalui tanaman obat keluarga. Yang menjadikan hal ini penting untuk dilakukan di Desa Singoyudan adalah banyaknya tanaman obat-obatan yang bisa dijadikan sebagai bahan obat-obatan keluarga akan tetapi banyak sekali masyarakat di desa tersebut yang belum memanfaatkan. Sehingga tanaman obat-obatan yang ada dibiarkan saja tanpa dimanfaatkan sedikitpun oleh masyarakat. Oleh karena itu, ada beberapa cara yang dapat dilakukan dalam pelaksanaan pengabdian ini diantaranya adalah sebagai berikut:

\section{a. Observasi}

Indonesia merupakan salah satu negara yang kaya akan rempah-rempah serta tumbuhan. Dengan kekayaan alam yang dimiliki maka pada zaman colonial banyak sekali bangsa-bangsa asing yang masuk ke Indonesia hanya untuk mengambil tanaman yang bisa dijadikan obat-obatan selain itu bangsa-bangsa asing tersebut juga mengambil rempah-rempah yang ada di indonesia. Dengan kekayaan alam yang dimiliki tersebut maka wajar jika sampai saat ini masih banyak sekali tanaman yang bisa dijadikan sebagai obat pendamping keluarga.

Salah satu desa yang mempunyai potensi tanaman untuk dijadikan obat-obatan adalah Desa Singoyudan Kecamatan Mirit, dimana berdasarkan hasil observasi yang telah kami lakukan banyak sekali tanaman yang tumbuh di sektiar kebun masyarakat. Adapun tanaman yang mayoritas tumbuh adalah tanaman yang bisa dijadikan sebagai obat-obatan sehari-hari. Selain itu tanaman yang tumbuh di sekitar 
kebun masyarakat tidak diolah sama sekali melainkan hanya dibiarkan tumbuh saja tanpa dimanfaatkan. Maka dari itu berdasarkan hasil observasi kami menyimpulkan bahwa penting sekali melakukan pemberdayaan masyarakat Desa Singoyudan melalui pemanfaatan tanaman disekitar untuk dijadikan sebagai obat-obatan.

Berdasarkan hasil pendataan yang kami lakukan dilokasi ada beberapa tanaman yang bisa dijadikan sebagai tanaman obat keluarga, diantaranya adalah sebgai berikut:

Tabel 1 Jenis Tanaman yang Ada di Desa Singoyudan

\begin{tabular}{|c|l|l|}
\hline No & \multicolumn{1}{|c|}{ Jenis Tanaman } & \multicolumn{1}{c|}{ Manfaat } \\
\hline 1 & Temulawak & Mengatasi masalah system pencernaan \\
\hline 2 & Jahe & $\begin{array}{l}\text { Mengatasi masalah system pencernaan terutama mengurangi } \\
\text { mual }\end{array}$ \\
\hline 3 & Kencur & $\begin{array}{l}\text { Menurunkan kolestrol dalam darah, meningkatkan nafsu } \\
\text { makan dan lain-lain }\end{array}$ \\
\hline 4 & Jeruk Nipis & $\begin{array}{l}\text { Memerangi infeksi, merejamkan kulit dan menurunkan gula } \\
\text { darah }\end{array}$ \\
\hline 5 & Jambu Batu & Mencegah kanker, meningkatkan imunitas tubuh dan lain-lain \\
\hline 6 & Pepaya & $\begin{array}{l}\text { Melancarakan pencernaan, menjaga kesehatan jantung, } \\
\text { mencegah kanker dan lain-lain }\end{array}$ \\
\hline 7 & Daun Jambu Batu & $\begin{array}{l}\text { Mengatasi diare, mengontrol diabetes, mengurangi gejala sakit } \\
\text { gigi dan gusi dan lain-lain }\end{array}$ \\
\hline 8 & Daun Pepaya & $\begin{array}{l}\text { Obat demam berdarah, menjaga kesehatan hati, redakan nyeri } \\
\text { menstruasi dan lain-lain }\end{array}$ \\
\hline
\end{tabular}

Sumber: diolah oleh tim pengabdian masyarakat

Dari hasil table di atas menunjukkan bahwa Desa Singoyudan mempunyai potensi yang belum dimanfaatkan sama sekali oleh masyarakat maupun Pemerintah Desa. Selain itu Desa Singoyudan juga mempunyai potensi pertanian yang sangat luar bisa, hal ini dapat dilihat dari mata pencaharian masyarakatnya serta tingkat kesuburan tanah yang ada di desa tersebut. Selain itu juga dapat dilihat dari jenisjenis tanaman yang ada di Desa Singoyudan masih banyak sekali yang belum dimanfaatkan untuk dijadikan sebagai pendamping obat keluarga.

Jenis tanaman yang ada di Desa Singoyudan merupakan tanaman yang masuk kategori tanaman obat keluarga, sehingga sangat bermanfaat sekali bagi masyarakat jika dimanfaatkan untuk obat pendamping keluarga. Hal ini belum dimanfaatkan secara maksimal oleh masyarakat dikarenakan masih minimnya pengetahuan mengenai manfaat dari jenis tanaman tersebut, sehingga masih sangat jarang masyarakat yang menggunakan tanaman tersebut sebagai alternative obat-obatan keluarga. Dengan adanya pendampingan pengabdian ini serta penyuluhan maupun sosialisasi yang akan dilakukan kepada masyarakat Desa Singoyudan harapannya bisa memanfaatkan tanaman tersebut sebagai obat pendamping keluarga.

\section{b. Sosialisasi dan Penyuluhan Manfaat Tanaman Obat Keluarga}

Berdasarkan hasil observasi yang telah kami lakukan maka tema yang akan diambil dalam pelaksanaan pengabdian ini adalah tentang "Pemberdayaan Masyarakat Melalui Tanaman Obat Keluarga". Dengan adanya tema tersebut harapannya masyarakat Desa Singoyudan bisa lebih mandiri serta bisa memanfaatkan tanaman 
disekitar untuk dijadikan sebagai obat-obatan keluarga. Hal ini dikarenakan secara geografis Desa Singoyudan merupakan desa yang berada di daerah pesisir dan jauh dari ibu kota Kabupaten. Maka dari itu perlunya pendampingan pengolahan tanaman sekitar untuk dijadikan sebagai obat keluarga. Berdasarkan pernyataan Hikmat dalam (Trisnaningsih, Wahyuni, \& Nur, 2019) bahwa pelaksanaan atau pemanfaatan tanaman obat keluarga akan bisa dilaksanakan dengan baik jika masyarakat juga memahai teknik budidaya tanaman obat keluarga (TOGA).

Pada pelaksanaan pengabdian ini memang dilakukan beberapa metode tahapan, salah satunya adalah sosialisasi. Kegiatan ini dilakukan guna memberi pengetahuan kepada masyarakat Desa Singoyudan mengenai pemanfaatan tanaman yang dijadikan sebgai obat-obatan. Karena desa tersebut mempunyai banyak potensi tanaman yang bisa dijadikan obat-obatan keluarga. Oleh karena itu, kami selaku pelaksana pengabdian melakukan kegiatan sosialisasi kepada masyarakat tentang manfaat tanaman yang bisa dijadikan sebagai obat-obatan.

Pada tahap sosialisasi ini lebih banyak difokuskan kepada jenis tanaman, mapun manfaat tanamah yang bisa dijadikan sebagai obat pendamping keluarga atau obat keluarga. Terutama mengenai tanaman yang mudah didapatkan oleh masyarakat karena banyak dijumpai di sekitar halaman atau kebun masyarakat Desa Singoyudan. Pelaksanaan kegiatan sosialisasi ini diikuti masyarkaat Desa Singoyudan terutama ibu-ibu PKK, dimana masyarakat tersebut mengikuti kegiatan dengan sangat antusias, hal ini dapat dilihat dari jumlah peserta yang hadir pada kegiatan sosialisasi dan penyuluhan. Mengingat untuk kegiatan pengabdian ini memang lebih difokuskan kepada ibu-ibu serta generasi muda dari Desa Singoyudan.

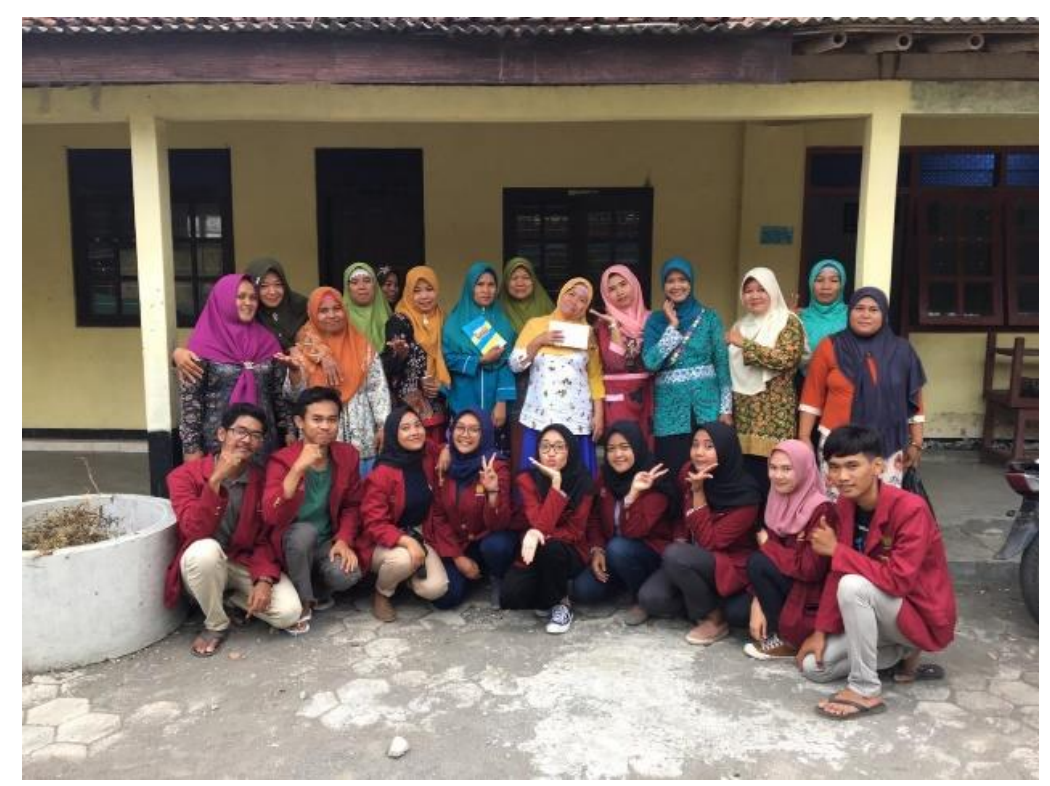

Gambar 1. Foto Kegiatan Sosialisasi dan Penyuluhan

Dengan adanya kegiatan sosialisasi dan penyuluhan ini harapannya masyarakat Desa Singoyudan bisa lebih paham mengenai jenis-jenis tanaman yang bisa dijadikan sebagai obat pendamping keluarga. Selain itu kegiatan ini juga melakukan praktik 
penyuluhan pembuatan obat. Adapun praktik tersebut diawali dengan pemahaman mengenai jenis tanaman dan manfaatnya terlebih dahulu. Dengan pemahan tersebut harapannya masyarakat Desa Singoyudan bisa memanfaatkan tanaman sekitar untuk dijadikan sebagai obat. Sehingga masyarakat bisa mengurangi obat-obatan yang berbahan kimia dan lebih mengutamakan obat-obatan herbal atau berbahan alami.

Selain melakukan sosialisasi dan praktik, pada pelaksanaan kegiatan ini juga dilakukan pembagian buku panduan tanaman obat keluarga. Buku panduan ini memuat jenis tanaman yang bisa dijadikan sebagai bahan obat-obatan serta manfaat tanaman tersebut. Sehingga dengan adanya buku panduan ini akan sangat bermanfaat bagi masyarakat serta mempermudah masyarakat dalam pembuatan obat pendamping keluarga dari tanaman disekitarnya. Harapannya dengan adanya pelaksanaan sosialisasi serta penyuluhan ini akan bermanfaat bagi masyarakat Desa Singoyudan, terutama dalam hal sharing pemanfaatan tanaman sekitar untuk dijadikan sebagai obat pendamping keluarga.

\section{c. Pembuatan Kebun Dan Penanaman}

Tahap selanjutnya dalam pelaksanaan pengabdian masyarakat ini adalah mengenai pembuatan kebun tanaman obat keluarga. Pembuatan kebun ini dilakukan dengan tujuan untuk mempermudah masyarakat dalam menyatukan tanaman yang bisa dijadikan sebagai obat-obatan. Sehingga dengan adanya kebun tanaman ini akan bermanfaat bagi masyarakat Desa Singoyudan terutama dalam hal pemanfaatan tanaman obat keluarga. Pada pelaksanaan pembuatan kebun ini tim pengabdian bekerjasama dengan pemerintah desa dan masyarakat, mengingat untuk pembuatan lahan atau kebun tanaman obat keluarga harus ada persetujuan dari pihak pemilik lahan. Sehingga dengan adanya persetujuan baik dari pemilik dan pemerintah desa pembuatan kebun atau lahan tanaman obat keluarga bisa berjalan dengan lancer dan baik.

Pada saat pembuatan kebun tim pengabdian bekerjasama dengan masyarakat untuk membuat kebun tanaman obat keluarga secara bersama-sama, selain ini pada proses penanaman juga dilakukan secara bersama-sama. Hal ini dilakukan dengan tujuan supaya masyarakat juga merasa memiliki tanaman obat keluarga tersebut, sehingga setelah pelaksanaan pengabdian dinyatakan selesai masyarakat masih tetap merawat serta memanfaatkan tanaman obat keluarga. Oleh karena itu, pada proses pembuatan awal sampai dengan proses penanaman masyarakat banyak yang ikut terlibat terutama ibu-ibu PKK yang memang menjadi salah satu sasaran atau objek pengabdian ini. 


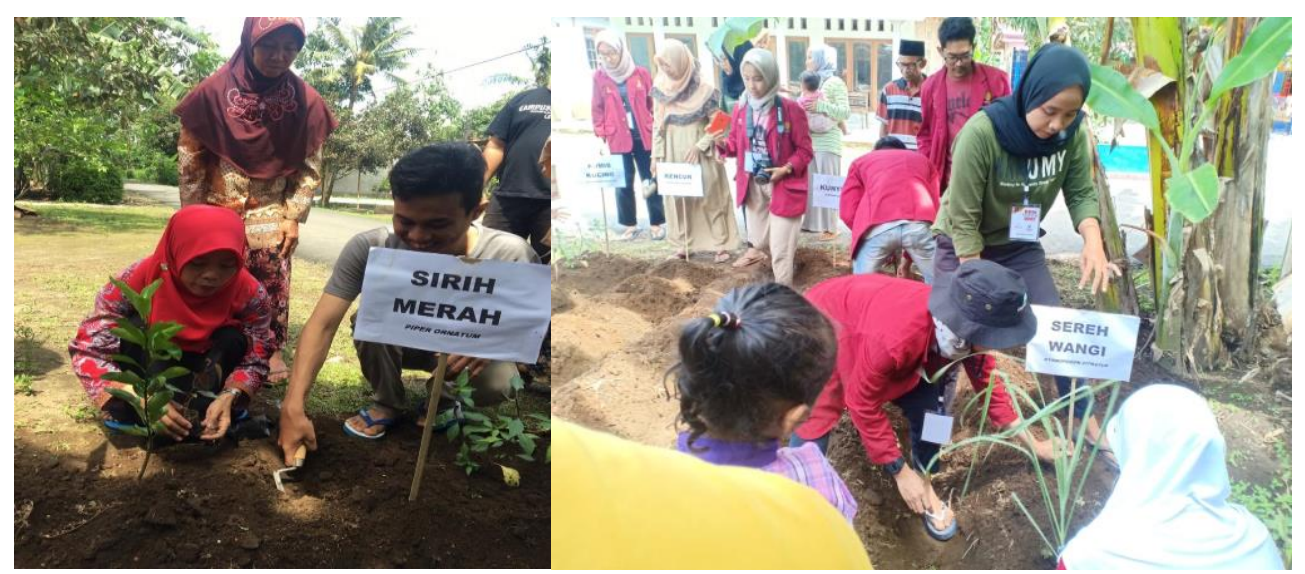

Gambar 2. Foto Kegiatan Pembuatan Kebun dan Proses Penanaman TOGA

Kebun atau lahan yang telah disiapkan dan dibuat ini ditanamai berbagai jenis tanaman yang mempunyai manfaat sebagai obat-obatan herbal. Terutama tanaman yang memang tidak ada di Desa Singoyudan, hal ini dilakukan guna melengkapi tanaman yang sudah ada di Desa Singoyudan. Mengingat potensi kesuburan alamnya yang sangat luar biasa maka kami sebagai tim pengabidian melakukan pembelian tanaman yang mudah untuk tumbuh dan perawatannya juga mudah. Selain itu pembelian tanaman ini juga dilihat dari manfaatnya yang paling banyak di gunakan oleh masyarakat sebagai bahan obat-obatan atau obat pendamping keluarga.

Pada peroses pelaksanaan ini juga masyarakat mempunyai andil besar terutama dalam pembuatan sampai penanaman, akan tetapi masih ada tahapan terakhir yang harus dilakukan oleh masyarakat yaitu proses perawatan kebun tanaman obat keluarga. Dengan adanya perawatan yang baik maka tanaman yang ditanam juga akan tumbuh dengan baik sehingga bisa bermanfaat bagi masyarakat secara umum dan khususnya masyarakat Desa Singoyudan. Pada kegiatan ini juga sangat didukung oleh pemerintah desa, harapannya dengan adanya kegaitan ini masyarakat Desa Singoyudan bisa lebih mandiri terutama dalam hal menjaga kesehatan keluarga. Karena Desa Singoyudan mempunyai beberapa permasalahan kesehatan diantaranya adalah masih tingginya angka stunting, dan pemerintah desa mempunyai target untuk menurunkan angka stunting tersebut.

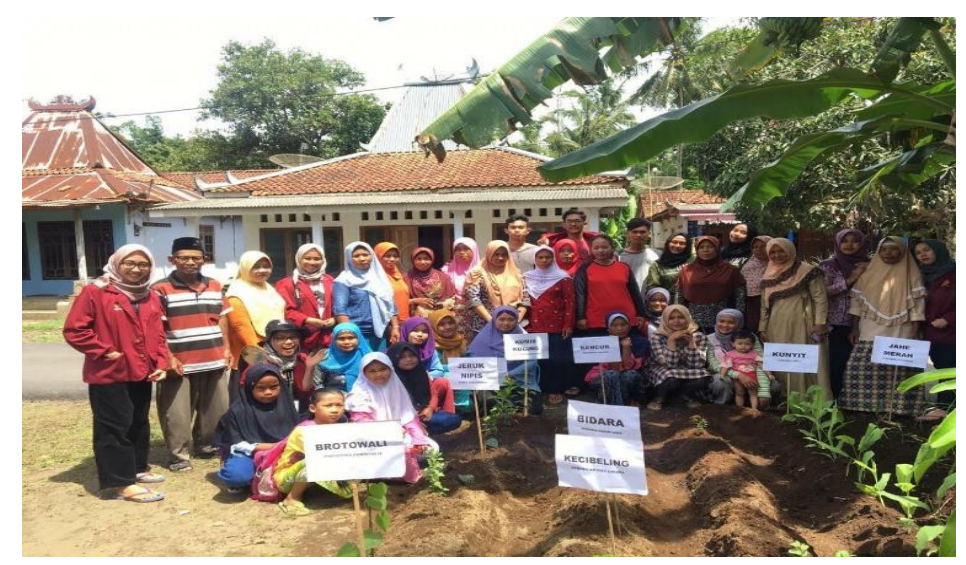

Gambar 3. Proses Penanaman Tanaman Obat Keluarga 
Pada pelaksanaan ini juga kami memberikan berbagai jenis tanaman yang bisa dijadikan sebagai bahan obat keluarga, diantarnaya adalah sebagai berikut:

Tabel 2 Jenis Tanaman Yang di Tanam di Kebun Obat Keluarga

\begin{tabular}{|c|l|l|}
\hline No & Jenis Tanaman & \multicolumn{1}{c|}{ Manfaat } \\
\hline 1 & Temulawak & Mengatasi masalah system pencernaan \\
\hline 2 & Jahe & Mengatasi masalah system pencernaan terutama mengurangi mual \\
\hline 3 & Kencur & $\begin{array}{l}\text { Menurunkan kolestrol dalam darah, meningkatkan nafsu makan, } \\
\text { menyembuhkan bantuk dan lain-lain }\end{array}$ \\
\hline 4 & Jeruk Nipis & Memerangi infeksi, merejamkan kulit dan menurunkan gula darah \\
\hline 5 & Jambu Batu & Mencegah kanker, meningkatkan imunitas tubuh dan lain-lain \\
\hline 6 & Pepaya & $\begin{array}{l}\text { Melancarakan pencernaan, menjaga kesehatan jantung, mencegah } \\
\text { kanker dan lain-lain }\end{array}$ \\
\hline 7 & Daun Jambu Batu & $\begin{array}{l}\text { Mengatasi diare, mengontrol diabetes, mengurangi gejala sakit gigi } \\
\text { dan gusi dan lain-lain }\end{array}$ \\
\hline 8 & Daun Pepaya & $\begin{array}{l}\text { Obat demam berdarah, menjaga kesehatan hati, redakan nyeri } \\
\text { menstruasi dan lain-lain }\end{array}$ \\
\hline 9 & Daun Bidara & Menyembuhkan luka, mengatasi keputihan, merawat rambut \\
\hline 10 & Kejibeling & Mengobati ambien/wasir, mengobati sakit \\
\hline
\end{tabular}

Sumber: diolah oleh tim pengabdian masyarakat

\section{Simpulan dan Rekomendasi}

Berdasarkan hasil pelaksanaan pengabdian yang telah dilakukan, maka kegiatan ini sangat bermanfaat bagi masyarakat Desa Singoyudan maupun pemerintah desa. Adapun manfaat yang bisa didapat oleh masayarakat maupun pemerintah adalah meningkatkan pengetahuan masyarakat terutama ibu-ibu PKK dalam pemanfaatan tanaman sekitar sebagai obat pendamping keluarga. Selain itu Desa Singoyudan juga merupakan salah satu desa yang baru pertama kali mendapatkan sosialisasi maupun penyuluhan mengenai pemanfaatan tanaman obat keluarga. Sehingga hal ini bisa dirasakan manfaatnya oleh masayarakat Desa Singoyudan. Adapun kegiatan yang dilakukan pada pelaksanaan pengabdian ini adalah observasi, sosialisasi dan penyuluhan manfaat tanaman obat keluarga, serta pembuatan kebun tanaman obat keluarga. Untuk kegiatan pertama, observasi dilakukan guna mendapatkan keinginan masyarakat terutama dalam hal pemanfaatan tanaman obat keluarga serta mendata jenis tanaman yang bisa dijadikan sebgai obat-obatan di Desa Singoyudan. Kedua, pelaskaan sosialisasi dan penyuluhan manfaat tanaman obat keluarga kegiatan ini dilakukan guna meningkatkan pengetahuan maupun pengalaman ibu-ibu PKK dalam memanfaatkan tanaman sebagai bahan obat-obatan. Ketiga, pembuatan kebun dilakukan guan menanam tanaman yang mempunyai manfaat buat kesehatan tertutama tanaman yang belum ada di Desa Singoyudan. Dengan adanya kegiatan ini masyarakat Desa Singoyudan bisa mengetahui manfaat tanaman yang bisa dijadikan sebgai obat-obatan pendamping keluarga maupun lebih mandiri dari segi kesehatan. Berdasarkan kegiatan yang telah dilakukan maka dapat diberikan rekomendasi, salah satunya adalah meningkatkan pemahaman masyarakat akan pentingnya tanaman sekitar untuk dijadikan sebagai obat pendamping keluarga. Selain itu juga mensosialisasikan kepada masyarakat untuk tetap melakukan pola hidup sehat dan bersih. Serta yang paling terakhir adalah memberikan pelatihan dan 
pendampingan secara rutin dalam pemanfaatan tanaman disekitar untuk obat pendamping keluarga.

\section{Penghargaan}

Terlaksananya kegiatan ini maka kami ucapkan terima kasih banyak kepada LP3M Universitas Muhammadiyah Yogyakarta yang telah mensuport kami untuk melaksanakan kegiatan pengabdian ini. Selain itu kami juga ucapkan terima kasih banyak kepada Pemerintah Desa dan masyarakat Singoyudan Kecamatan Mirit yang telah memberikan kami kesempatan untuk melaksanakan pengabdian di Desa Singoyudan. Kami ucapkan juga terima kasih banyak kepada tim pelaksanan pengabdian terutama mahasiswa KKN-PPM kelompok 169 dan kolega tim pengabdian masyarakat di Desa Singoyudan Kecamatan Mirit Kabupaten Kebumen Jawa Tengah.

\section{Daftar Pustaka}

Karo-Karo, U. (2010). Pemanfaatan Tanaman Obat Keluarga di Kelurahan Tanah 600, Medan. Kesmas: Jurnal Kesehatan Masayarakat Nasional, 4(5). https://doi.org/10.21109/kesmas.v4i5.169

Nurjanah, S. rahayu, Nurazizah, N. N., Septiana, F., \& Shalikhah, N. D. (2019). Peningkatan Kesehatan Masyarakat melalui Pemberdayaan Wanita dalam Pemanfaatan Lahan Pekarangan dengan Tanaman Obat Keluarga (TOGA) di Dusun Semawung. Community Empowernment, 4(1), 20-25. https://doi.org/10.33084/pengabdianmu.v2i2.63

Pemkab Kebumen Berkomitmen Tekan Angka Stunting. (2018). Retrieved from Humas Pemkab Kebumen website: https://baghumas.kebumenkab.go.id/index.php/web/read/recent/pemkab-kebumenberkomitmen-tekan-angka-stunting

Qamariah, N., Handayani, R., \& Novaryatiin, S. (2019). Peningkatan Pengetahuan dan Keterampilan Ibu Rumah Tangga Dalam Pengolahan Tanaman Obat Keluarga (TOGA) Sebagai Ramuan Obat Tradisional. Jurnal Ilmiah Pengabdian Kepada Masyarakat, 4(1), 50-54.

Susanto, A. (2017). Komunikasi Dalam Sosialisasi Tanaman Obat Keluarga (Toga) Di Kecamatan Margadana. Jurnal Para Pemikir, 6(1), 111-117. https://doi.org/10.30591/PJIF.V6I1.476.G429

Trisnaningsih, U., Wahyuni, S., \& Nur, S. (2019). Pemanfaatan Lahan Pekarangan Dengan Tanaman Obat Keluarga. JPPM (Jurnal Pengabdian Dan Pemberdayaan Masyarakat), 3(2). https://doi.org/10.30595/jppm.v3i2.4554. 